\title{
Editorial
}

\section{Resurgence of non-communicable diseases in LMICs: a cause for concern?}

\author{
James K Tumwine
}

EIC, African Health Sciences.

DOI: https://dx.doi.org/10.4314/ahs.v19i2.3

Cite as: Tumwine JK. Resurgence of non-communicable diseases in LMICs: a cause for concern? Afri Health Sci.2019;19(2): VI-VIII. https:/ / dx.doi.org/10.4314/abs.v19i2.3

This editorial is devoted solely to non-communicable diseases (NCDs) papers published in the 2019 June issue of African Health Sciences. This is a departure from $A H S$ practice of having one editorial per issue. This time, we have decided to have three thematic editorials, which will help our readers focus attention on the themes of their choice. The other areas of interest in this June issue of African Health Sciences are sexual/reproductive and child health; as well as infectious diseases, which have had 2 separate editorials, written by Prof. Grace Ndeezi, and Dr. David Mukunya.

\section{Now to NCDs}

We begin with three interesting papers on the cardiovascular system. Adje and others ${ }^{1}$, have written a research paper on cardiovascular risk assessment from a community in Nigeria.

In a study of adults aged 40-80 years, they found that up to $30 \%$ were hypertensive and a similar proportion was overweight, and had abnormal cholesterol levels. Scientists from $\mathrm{China}^{2}$, on the other hand, carried out a meta-analysis, which showed that levels of triglyceride and glucose were the predisposing factors for ischemic stroke in the Asian population. Finally, Ifeluwa and others ${ }^{3}$ demonstrated impaired right ventricular systolic function of patients with heart failure secondary to hypertension in Ibadan Nigeria. These remind us that cardiovascular diseases are no longer the preserve of people in high income countries.

The next set of papers is on cancer, which has become ubiquitous and dominates conversations in the social media, clubs, restaurants, taxis, bodabodas, buses and work places in Africa! Hence, Mohammedi and others ${ }^{4}$ report on cyclin D1 over-expression in Algerian breast cancer women. They conclude that this could be considered for routine diagnosis of breast cancer. On the other hand, Indian scientists report on the association of inflammatory biomarkers with lung cancer in a North Indian population. They conclude that ' $\mathrm{CRP}$, TNF- $\alpha$, IL-6 and IL-8 are the promising biomarkers in the identification of lung cancer patients" ${ }^{5}$. Cancer chemotherapy has unpleasant cytotoxic effects. In the next paper, the authors found that polysaccharides from mycelia of Cordycepsmilitarisa melioratedcytotoxic effects from doxorubicin ${ }^{6}$.

Another paper ${ }^{7}$ is on diabetes mellitus, and reports on the lack of association between vitamin $\mathrm{D}$ receptor gene BsmI polymorphism, and type 2 diabetes mellitus in Pakistani populations. An important negative finding!

\section{Now to mental health and other issues}

A study from Uganda reports on mental health professionals' views on exercise for people with mental illness ${ }^{8}$, while work from South Africa reports on the disuse of hearing aids in the elderly with presbycusis? ${ }^{9}$. Other authors from South Africa assert that hospital-acquired acute kidney injury (AKI) in adults is associated with adverse patient outcomes. They recommend automated electronic alerts to empower health workers, detect and manage the $\mathrm{AKI}^{10}$. Saudi authors on the other hand report that aerobic exercise modulates cytokine profile and sleep quality in the elderly ${ }^{11}$.

What follows is a diverse group of papers on several aspects of NCDs. From Turkey we have staff perceptions of patient safety culture and safety grades in general surgery departments ${ }^{12}$.

Zimbabwean researchers found that $A$. stenophyllaaqueous extract increases glucose uptake partly through increasing the GLUT 4 mRNA and translocation potentially acting via the PI-3-K pathway ${ }^{13}$. The study confirms 'the ethno-

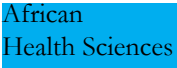

(C) 2019 Tumwine JK. Licensee African Health Sciences. This is an Open Access article distributed under the terms of the Creative commons Attribution License (https://creativecommons.org/licenses/BY/4.0), which permits unrestricted use, distribution, and reproduction in any medium, provided the original work is properly cited. 
pharmacological uses of A.stenophylla' especially its potential for treating diabetes mellitus.

The next set of papers is relevant to education in NCDs. We have a paper on colour vision deficiency among students in Lagos State, Nigeria ${ }^{14}$, followed by a faculty's experiences of a formal mentoring programme ${ }^{15}$, and one on the effect of nutrient intakes on anthropometric profiles among university students in Malaysia ${ }^{16}$. Kose's paper on the effectiveness of basic life support training on nursing students' knowledge and basic life support practices is the jewel in the crown of this pedagogy section ${ }^{17}$. It is followed by a description of the challenges faced by student accoucheurs during clinical placement at the free state maternal health care institutions in South Africa ${ }^{18}$. Surprisingly, Ugandan researchers report that parental involvement was not associated with academic achievement among deaf children in Kampala ${ }^{19}$. They recommend a search for other factors associated with academic achievement in the deaf children. Nigerian authors report that using real time sonography as an anatomy teaching aid was the least popular method among undergraduate students ${ }^{20}$. The implications are not clear given the lack of cadavers in medical schools worldwide. We end with a few case reports: one on rectus sheath hematoma and retroperitoneal bleeding due to rivarox$\mathrm{aban}^{20}$; and the other on diagnostic challenges and surgical management of osteoblastoma and aneurysmal bone cyst of the lumbar spine in a child ${ }^{22}$.

This treatise reflected on a wide range of non-communicable diseases, which reminds us that these NCDS are diverse. That they are on the rise in LMIC is an understatement. Individuals, researchers and policy makers need to keep on the alert, with a view to preventing the NCDs. Ensuring universal health access is a key priority, in line with the sustainable development goals.

\section{References}

1. Adje DU, Williams FE, Oparah AC. Outcome of cardiovascular risk assessment among rural community dwellers in Ezionum, Nigeria-implications for public health. Afri Health Sci. 2019;19(2). 2112-2120. https:// dx.doi.org/10.4314/ahs.v19i2.35

2. Cui Q, NA N. Modifiable and non-modifiable risk factors in ischemic stroke: a meta-analysis. Afri Health Sci. 2019;19(2). 2121-2129. https://dx.doi.org/10.4314/ahs. v19i2.36
3. Ifeoluwa A A, Adewole AA, Abiodun AM, Akinyemi A. Right ventricular systolic function in Nigerians with heart failure secondary to hypertensive heart disease. Afri Health Sci. 2019;19(2). 2130-2139. https://dx.doi. org/10.4314/ahs.v19i2.37

4. Mohammedi F, Doula FD, Mesli F, Senhadji R. Cyclin D1 overexpression in Algerian breast cancer women: correlation with CCND1 amplification and clinicopathological parameters. Afri Health Sci. 2019;19(2). 2140-2146. https://dx.doi.org/10.4314/ahs.v19i2.38

5. Gaur P, Bhattacharya S, Kant S, Kushwaha R.A.S., Garg R, Singh G, et al. Association of inflammatory biomarkers with lung cancer in North Indian population. Afri Health Sci. 2019;19(2). 2147-2155. https://dx.doi. org/10.4314/ahs.v19i2.39

6. Ruo-Kai L, Chen-Yen C, Wei-Hsuan H, Chen-Jei T, Cheng-Jeng T. Polysaccharides obtained from mycelia of Cordyceps militaris attenuated doxorubicin-induced cytotoxic effects in chemotherapy. Afri Health Sci. 2019;19(2). 2156-2163. https://dx.doi.org/10.4314/ahs.v19i2.40

7. Fatma H, Abdul SN. Association of vitamin D receptor gene BsmI polymorphism with type 2 diabetes mellitus in Pakistani population. Afri Health Sci. 2019;19(2). 2164-2171. https://dx.doi.org/10.4314/ahs.v19i2.41

8. Vancampfort D, Stanton R, Probst M, De Hert M, van Winkel R, Myin-Germeys I, et al. A quantitative assessment of the views of mental health professionals on exercise for people with mental illness: perspectives from a low-resource. Afri Health Sci. 2019;19(2). 2172-2182. https://dx.doi.org/10.4314/ahs.v19i2.42

9. Nomfundo M, Nikita V. The disuse of hearing aids in elderly people diagnosed with a presbycusis at an old age home, in Johannesburg, South Africa: a pilot study. Afri Health Sci. 2019;19(2). 2183-2188. https://dx.doi. org/10.4314/ahs.v19i2.43

10. Fenna K, Erasmus RT, Zemlin AE. Hospital-acquired acute kidney injury prevalence in adults at a South African tertiary hospital. Afri Health Sci. 2019;19(2). 21892197. https://dx.doi.org/10.4314/ahs.v19i2.44

11. Abd El-Kader M, Al-Jiffri OH. Aerobic exercise modulates cytokine profile and sleep quality in elderly. Afri Health Sci. 2019;19(2). 2198-2207. https://dx.doi. org/10.4314/ahs.v19i2.45

12. Teleş M, Kaya S. Staff perceptions of patient safety culture and safety grades in general surgery departments in Turkey. Afri Health Sci. 2019;2019(2). 2208-2218. https://dx.doi.org/10.4314/ahs.v19i2.46

13. Taderera T, Chagonda LS, Gomo E, Katerere D, Shai 
LJ. Annona stenophylla aqueous extract stimulates glucose uptake in established $\mathrm{C} 2 \mathrm{Cl} 2$ muscle cell lines. Afri Health Sci. 2019;19. 2219-2229. https://dx.doi.org/10.4314/ahs. v19i2.47

14. Oduntan OA, Mashige KP, Kio FE. Colour vision deficiency among students in Lagos State, Nigeria. Afri Health Sci. 2019;19(2). 2230-2236. https://dx.doi. org/10.4314/ahs.v19i2.48

15. Roets L, van Rensburg EJ, Lubbe J. Faculty's experiences of a formal mentoring programme: the perfect fit. Afri Health Sci. 2019;19(2). 2237-2242. https://dx.doi. org/10.4314/ahs.v19i2.49

16. Koo HC, Hadirah Z, Airina A, Nurul Alifatul Amrina R, Faziela N. Effect of nutrient intakes on anthropometric profiles among university students from a selected private University in Klang Valley, Malaysia. Afri Health Sci. 2019;19(2). 2243-2251. https://dx.doi.org/10.4314/ ahs.v19i2.50

17. Kose S, Akin S, Mendi O, Goktas S. The effectiveness of basic life support training on nursing students' knowledge and basic life support practices: a non-randomized quasi-experimental study. Afri Health Sci. 2019;19(2). 2252-2262. https://dx.doi.org/10.4314/ahs.v19i2.51

18. Sibiya M, Madlala S, Ngxongo T. Challenges faced by student accoucheurs during clinical placement at the free state maternal health care institutions. Afri Health Sci. 2019;19(2). 2263-2269. https://dx.doi.org/10.4314/ahs. v19i2.52

19. Akellot J, Bangirana P. Association between parental involvement and academic achievement of deaf children at Mulago school for the deaf, Kampala, Uganda Afri Health Sci. 2019;19(2). 2270-2281. https://dx.doi. org/10.4314/ahs.v19i2.53

20. Umar MS, Zira JD, Ogenyi PA, Njokwu G, Malgwi FD, Silas MA, et al. Real Time Sonography as an anatomy teaching aid in undergraduate radiography institutions in Northern Nigeria. Afri Health Sci. 2019;19(2). 2282-2289. https://dx.doi.org/10.4314/ahs.v19i2.54

21. Börekci E. Rectus sheath hematoma and retroperitoneal bleeding due to rivaroxaban: a case report. Afri Health Sci. 2019;19(2). 2290-2293. https://dx.doi.org/10.4314/ ahs.v19i2.55

22. Ibebuike K, Roussot M, Watt J, Skead G, Dunn R. Diagnostic challenges and surgical management of co-existent osteoblastoma and aneurysmal bone cyst of the lumbar spine in a child: case report. Afri Health Sci. 2019;19(2). 2294-2301. https://dx.doi.org/10.4314/ahs. v19i2.56 